\title{
MODERN MEANS OF PRODUCTION AND THE STAFF AWARENESS OF THE TECHNICAL IN THE PLANT OF THE MINING INDUSTRY
}

Dorota Palka, ${ }^{1}$ Jaroslaw Brodny, ${ }^{2}$ Kinga Stecula ${ }^{3}$

\begin{abstract}
The rapid rate of introducing new technology leads to the issue of staff awareness in operating the latest equipment. Many users do not understand how new devices work and how to use the new machines and gadgets. This article presents the results of research aimed at determining the influence of new technology on the technological awareness of mining workers. Surveys and advanced expert interviews have shown that the lack of technical knowledge means the introduced changes are often perceived negatively by staff and that the main reason for this outcome is the absence of effective education. Lack of knowledge means that frequently the effectiveness of the new and technologically advanced machines is marginal. Presented problems due to the high competition in the energy market have a crucial practical significance. The results of this research may be valuable as a source of information and knowledge for companies.
\end{abstract}

UDC Classification: 622.8; DOI: http://dx.doi.org/10.12955/cbup.v5.1094

Keywords: mining, employees' awareness, technological culture, technology assessment

\section{Introduction}

The increasing competition in the world energy market has adversely affected the hard coal market. Recently, Polish mining has faced serious economic challenges relating to the efficiency of work and the profitability of mines. The expectations of mine workers regarding salaries and overall improvement in the standard of living have increased. However, in the current economic situation, mining companies are not able to meet these expectations. At the current level of employment, the increase in wages sought is deemed impossible for these companies to meet. The main reason is that the industry employs too many people. Nevertheless, another reason for this situation is the low efficiency of the mining industry. The technical and organizational modernization of the mining industry provides an opportunity to improve this situation.

Organizational modernization could advance the situation through introducing modern management systems for mining companies, organizational restructures, and new ways of organizing the complete labor system. Improvement could also arise from optimizing employment and cooperation between all personnel working in the mine (Fayyad, Wierse, \& Grinstein, 2002).

Technical modernization mainly involves the introduction of constantly improved, more efficient and modern machines and devices. The purpose of such modernization is to base mining on knowledge. Effective mining of hard coal requires the use of ever-increasing technology of exploitation, implementation of innovative mechanical systems, as well as advanced safety systems limiting the risk of adverse events (Ławniczak, Mazurek, Iwanowicz, \& Mrugalska, 2013)

High competition in the raw energy resources market and dynamic changes in the global economy force mining companies to introduce modern technologies. It is necessary to optimize the cost and time of production, while at the same time shaping the environment in terms of work safety (Walczyna \& Lucjan, 2012).

In summary, the aim of all these activities is to improve the economic efficiency of mining enterprises, which should, in turn, also contribute to improving their employees' livelihood.

One such effort to improve mining productivity is the introduction of increasingly modern, safe, efficient, and reliable mining machinery. In practice, it has emerged, that despite significant costs incurred for the purchase and introduction of these machines for production, there has been no significant increase in productivity of the mines. The economic effects of the investment have been unsatisfactory.

An analysis into the causes of this situation revealed that only marginal increases in efficiency result from using these highly efficient and costly machines (Brodny, Stecuła, \& Tutak, 2016; Stecuła \&

\footnotetext{
${ }^{1}$ Dorota Palka,Faculty of Organization and Management, Silesian University of Technology, dorota.palka@polsl.pl

2 Jarosław Brodny, Faculty of Organization and Management, Silesian University of Technology, jaroslaw.brodny@ polsl.pl

${ }^{3}$ Kinga Stecuła,, Faculty of Organization and Management, Silesian University of Technology, kinga.stecula@polsl.pl
} 
Brodny, 2016). Studies indicated that, in the area of efficient use of machinery, measures are needed to effectively reduce production costs. It must be assumed that one of the main reasons for improving the economic condition of mining enterprises is their technical modernization. Only in using modern machinery and equipment to their full potential can opportunities arise for the efficient operation of these companies. For this process to be successful, it is necessary to have a suitably trained crew who are convinced of the necessary changes (Guo-fa, 2010).

Employees, as beneficiaries, need to be extremely interested and strongly supportive of the changes. It is, therefore, necessary to educate employees about the need for change and implement appropriate training. The modern machinery required for operation requires proper maintenance and introducing innovative technical solutions requires proper preparation of employees. The employees' high cultural and technical awareness are necessary to handle these machines and improve their efficiency (Robson, Stephenson, Schulte, Amick, Irvin, Eggerth, \& Peters, 2012).

This article presents the results of surveys and in-depth expert interviews, aimed at identifying barriers and problems experienced by mine workers when modern technical means are introduced. The results of these studies have shown that, with the introduction of modern technical solutions, intensive educational activities are required for the employees. In the absence of such measures, it is very difficult to achieve the expected effects of these changes.

\section{Survey Research}

This study aimed to determine the state of technical awareness in mining enterprises by surveying employees of these companies. Another purpose of this study was to determine the reasons for low efficiency in use of modern machines owned by these companies

Anonymous surveys were conducted among employees of mining companies. The survey consisted of three parts, containing a total of 12 questions. The first part involved verifying the details of the respondents, including age, seniority, and education. The second part contained closed questions concerning modern technologies and technical measures introduced at the mine. The third part contained open questions to explore the subjective opinions of the respondents.

The first question in the second part concerned employees' views on the need for modern, innovative, technical solutions in the mine. Figure 1 shows the answers to this question.

\begin{tabular}{|l|l|}
\hline Figure 1: The need to introduce modern solutions in the mine - Question 1, Part 2 \\
\hline & $\begin{array}{l}\text { Ihave no } \\
\text { opinion }\end{array}$ \\
\hline
\end{tabular}

The results show that as many as $68 \%$ of the respondents regarded introducing modern technical equipment in the mining industry negatively. Only $27 \%$ supported their introduction, and $5 \%$ had no opinion on this topic.

Such a large group of opponents of technical progress is highly disturbing and may indicate the workers' lack of technical awareness. Another question asked the reasons for the answers given in the first question. Particularly interesting are the responses from the respondents who had a negative attitude to the changes. 
The most frequently cited reason was the lack of ability to handle modern machines and equipment, as well as the lack of thorough technical knowledge about the operation and functionality of these devices. More than $70 \%$ indicated a lack of skills and knowledge needed to work with modern technology. There were also fears of being exposed to an unknown technique and of the reaction of colleagues to the situation when revealing the lack of their ability to use modern machines and devices. Figure 2 shows the detailed results of these responses

\begin{tabular}{|c|c|c|}
\hline Figure 2: The reasons for the negative attitude to technology & \\
\hline Lack of handling skills & \\
Lack of technical knowledge & \\
Fear of the unknown & \\
Fear of reaction of a colleague & \\
Other & $17 \%$ \\
\hline
\end{tabular}

Another question required the respondent to indicate the machine that, according to staff, required the most technical knowledge. In response, $44 \%$ of respondents pointed to a shearer and $39 \%$ to a lift machine (Figure 3). These results appear to reflect the actual technical level of these machines.

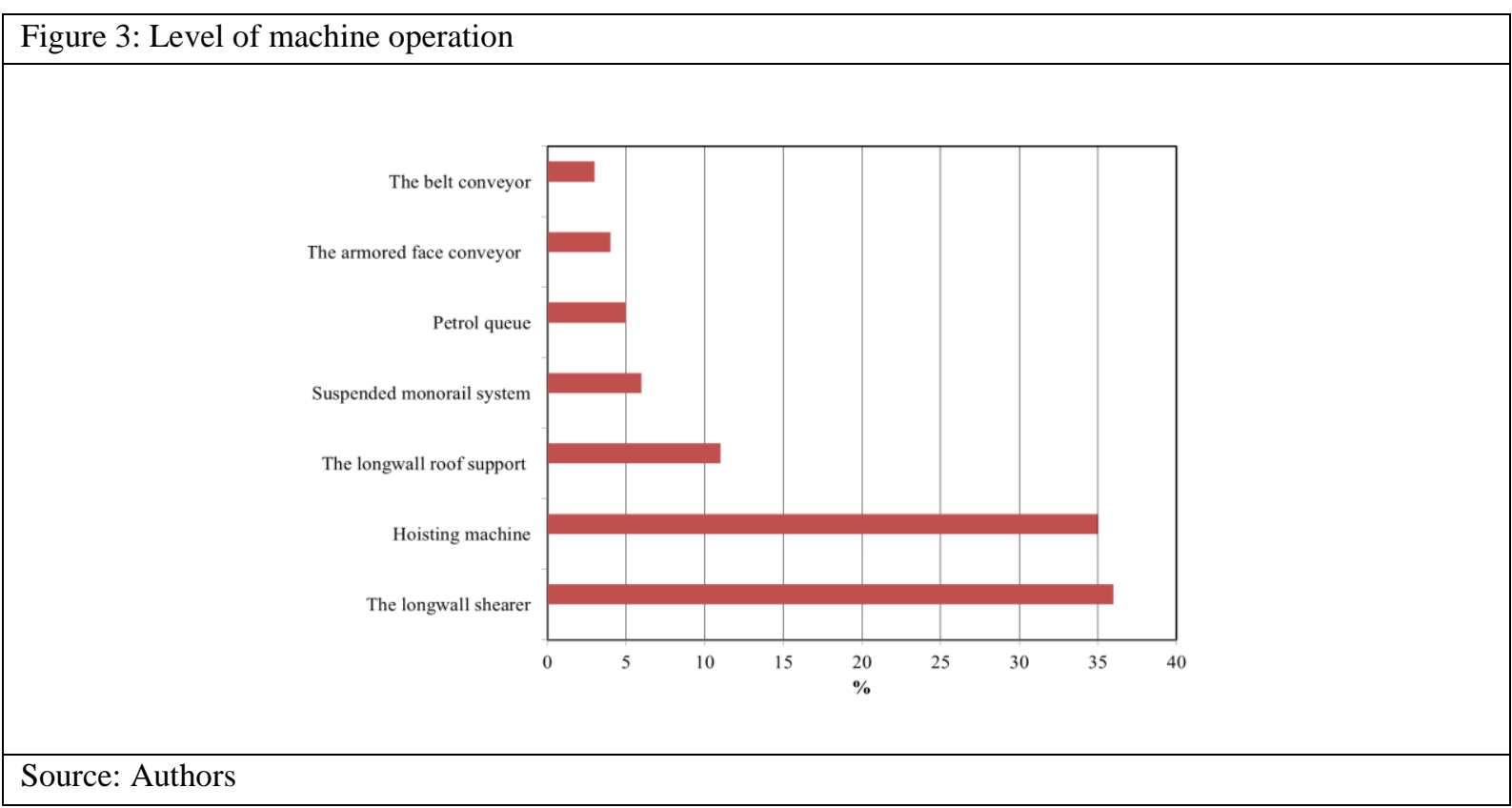

The next question was about willingness to participate in training to raise the technical knowledge of employees. In this case, the results referred to individual age groups of the respondents. The youngest individuals were the most interested in the training of new technologies. With increasing age, the number of workers interested in such training decreased. Figure 4 shows the results. 


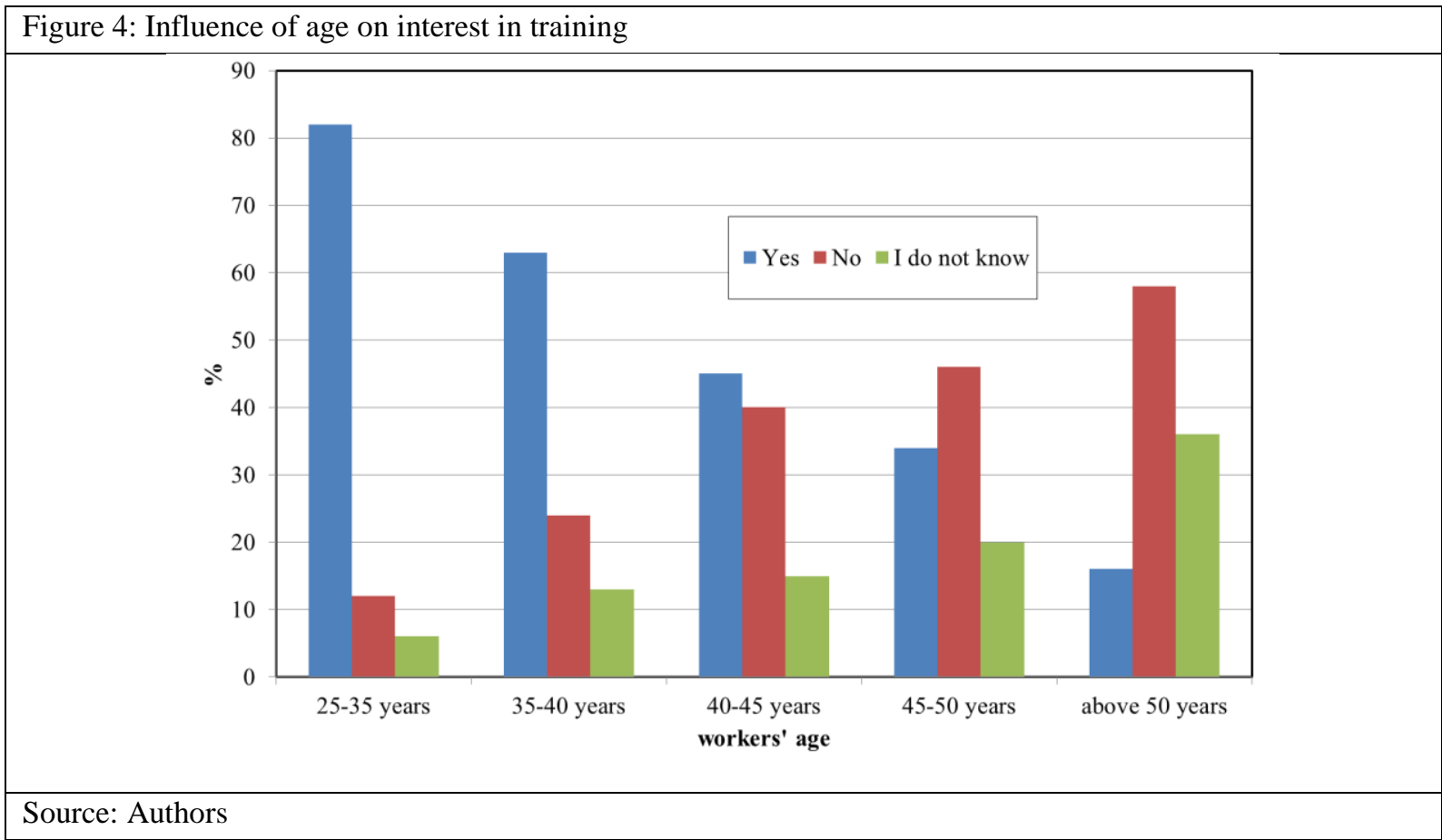

The questionnaire also included questions about employees' expectations and solutions to problems arising in their work. The diversity of responses revealed some problem areas that were discussed during expert interviews. Most employees recognized that the reason for ineffective work was an inadequate training program to prepare them for the required tasks. Both in-house training and vocational training programs did not contain sufficient knowledge about modern, innovative machines.

\section{Expert Interviews}

In-depth expert interviews with selected employee groups were conducted to better diagnose issues relating to the introduction of the modern means of production and technical awareness of employees. Results indicated that the major problem for these workers appeared to be the lack of an appropriate training system in the mines. This response indicated there was no possibility for deepening the knowledge and technical awareness of employees. The lack of promoting technical culture among the company's crew has vital influence. The concept of technical culture may, in this case, be broadly understood. It concerns both the quality and availability of technical documentation and tools, as well as thorough knowledge of employees. Basic information on machine construction and functionality and analytical thinking enable workers to anticipate and prevent unauthorized events. This situation has a significant impact on the safety of workers in their challenging conditions. Especially, correct handling of machinery and equipment allows for failure prediction and prevention (Tomaszewski \& Czekaj, 2009). Also, with a low level of technical culture more failure of machines and equipment is possible and this situation potentially increases the cost of repairs and complete overhauls.

The interviews also showed that employees who lacked sufficient technical knowledge were unaware of the consequences and costs of their actions. It is, therefore, essential that every company has a proper training policy, both in terms of safety and technical knowledge.

\section{Conclusion}

The abrupt pace of new technology deployment means that employees have problems handling and utilizing the full functionality of the advanced solutions. Many users seem unable to keep up with understanding how the latest machinery works and what follows is that they do not know how to operate the latest innovative machines and equipment. This predicament leads to a situation in which the machines are underutilized, and the company fails to achieve its business goals.

The surveys and expert interviews conducted among mine workers ascertained that one main cause of this state is the shortfall in educating employees. Deficiencies are mainly related to technical knowledge. The results clearly show that both the company's in-house training system and the school education system cannot adequately prepare a technician. 
This outcome is the result of the rapid introduction of new and innovative solutions that are a momentous challenge for some employees. Problems with handling and understanding the essence of these devices make these employees reluctant to introduce new machines and equipment.

Low technical awareness causes fears of using advanced technical equipment, stress, and dissatisfaction with work among the crew. Employees are often unaware of the costs generated by their misbehavior and ignorance. The lack of a proper level of technical culture makes the efficiency of using new and technologically advanced machines insignificant.

The results clearly show that mining companies should use all types of training, including technical. Raising the technical awareness of employees may prove to be a highly successful investment in the future. The training program in this area does not necessarily need to cause an additional financial burden for enterprises. Some of the training could be run by companies producing and supplying these mines.

Because of the high competition in the energy market, the presented issue is of great practical importance. The research results presented in the article may constitute an important source of information and knowledge for companies introducing modern technical measures.

\section{References}

Brodny, J., Stecuła, K., Tutak, M. (2016). Application of the TPM strategy to analyze the effectiveness of using a set of mining machines. Proceedings of 16th International Multidisciplinary Scientific GeoConferences SGEM 2016, Book 1, Vol. II, Albena Bulgaria, 65-72. DOI: 10.5593/SGEM2016/B12/S03.009.

Fayyad, U. M., Wierse, A., Grinstein, G. G. (2002). Information visualization in data mining and knowledge discovery. Morgan Kaufmann.

Guo-fa, W. A. N. G. (2010). Innovation and Development of Completed Set Equipment and Technology for High Efficient Coal Mining Face in Underground Mine [J]. Coal Science and Technology, 1, 022.

Ławniczak, I., Mazurek, P., Iwanowicz, A., Mrugalska, B. (2013). Innowacyjne rozwiązania i metody udoskonalania systemów bezpieczeństwa w przedsiębiorstwie. Prace Naukowe Akademii im. Jana Długosza w Częstochowie. Technika Informatyka, Inżynieria Bezpieczeństwa, 1.

Robson, L. S., Stephenson, C. M., Schulte, P. A., Amick III, B. C., Irvin, E. L., Eggerth, D. E., ... \& Peters, R. H. (2012). A systematic review of the effectiveness of occupational health and safety training. Scandinavian journal of work, environment \& health, 193-208

Stecuła, K., Brodny, J. (2016). Application of the OEE model to analyze the availability of the mining armored face conveyor. Proceedings of 16th International Multidisciplinary Scientific GeoConferences SGEM 2016, Book 1, Vol. II, Albena Bulgaria, 57-64. DOI: 10.5593/SGEM2016/B12/S03.008.

Tomaszewski, Z., \& Czekaj, A. (2009). Bezpieczeństwo w konstrukcji i użytkowaniu maszyn i urządzeń. Obróbka Plastyczna Metali, 20, 52-71.

Walczyna, A.,Łucjan, I. (2012). Postęp techniczny a humanizacja pracy. Postępy Nauki i Techniki, 190-198. 